\title{
Anticipating rotavirus vaccines: review of epidemiologic studies of rotavirus diarrhea in Argentina ${ }^{1}$
}

\author{
Jorge A. Gómez, ${ }^{2}$ Silvia Nates, ${ }^{3}$ Nelda R. De Castagnaro, ${ }^{4}$ \\ Carlos Espul, ${ }^{5}$ Ana Borsa, ${ }^{6}$ and Roger I. Glass ${ }^{7}$
}

\begin{abstract}
Rotavirus is the most common cause of severe diarrhea in children worldwide, and vaccines currently being field-tested could be available for childhood immunization in several years. To assess the rotavirus disease burden in Argentina and the value of future national surveillance for the disease, we reviewed available data on rotavirus detections reported by published and unpublished studies conducted in nine Argentine cities and by a multicenter study. Data from these studies indicated that rotavirus was detected in $20 \%$ of 5226 specimens (within a range of $6 \%$ to $54 \%$ for different studies) from children hospitalized for diarrhea and in 9\% of 6587 specimens (within a range of $5 \%$ to $22 \%$ for different studies) from children who were outpatients, members of mixed populations (hospitalized patients and outpatients), or survey subjects in community-based studies. The hospital data showed that while rotavirus was detected throughout the year, a peak occurred during the winter months (May-July), when up to half of the children with diarrhea were found positive for rotavirus. Attempted serotyping of 294 rotavirus-positive specimens for G-protein by three laboratories was successful in 230 cases (78\%); the resulting data indicated that serotype G1 was the most common (being present in $60 \%$ of the successfully serotyped specimens), followed by G2 (in 20\%), G4 (in 14\%), and G3 (in 5\%). Based on national data for Argentina, we estimate that in 1991 there were roughly 84500 rotavirus-associated outpatient visits (1 for every 8 births) and 21000 hospitalizations averaging 4 days in length ( 1 for every 31 births), all of which entailed direct medical costs estimated at US\$27.7 million. These preliminary data show that the rotavirus disease burden in Argentine children is extensive and could be decreased by a safe and effective vaccine. Further surveillance is needed to improve our understanding of the epidemiology and distribution of rotavirus strains in Argentina, to more accurately assess the cost-effectiveness of a rotavirus vaccine program, and to indicate what methods might best be used to monitor such a program's impact.
\end{abstract}

1 This article will also be published in Spanish in a forthcoming issue of this journal.

2 Ministry of Health and Social Action, National Institute of Infectious Diseases, Buenos Aires, Argentina. Mailing address: Departamento de Virología, Instituto Nacional de Enfermedades Infecciosas, Av. Velez Sarsfield 563, (1281) Buenos Aires, Argentina. Telephone: 54-1-301-7428; fax: 54-1-303-2382; e-mail: jgomez@cvtci.com.ar

3 National University of Córdoba, “Dr. J. M. Vanella" Institute of Virology, Córdoba, Argentina.

4 National University of Tucumán, Institute of Microbiology, Tucumán, Argentina.
Diarrhea is one of the most common problems of children worldwide. In developing countries it has been esti-

5 Central Hospital of Mendoza, Virology Laboratory, Mendoza, Argentina.

6 Children's Hospital of La Plata, Virology Laboratory, Buenos Aires, Argentina.

7 Centers for Disease Control and Prevention, Viral Gastroenteritis Section, Atlanta, Georgia, U.S.A. mated that acute diarrhea is responsible for 3.5 to 4 million deaths each year (1). In 1993, Argentine health authorities reported more than 400 deaths associated with unspecified diarrhea (ill-defined intestinal infections, I.C.D. code 009) (I. Miceli, personal communication, 1995). Similarly, diarrhea in children is a major cause of both hos- 
pitalizations and doctor visits, but the numbers have never been quantified or the agents well documented.

Since the discovery of rotavirus by Bishop et al. in 1973 (2), many epidemiologic studies have documented rotavirus as being the most important worldwide agent of severe childhood diarrhea. Most primary rotavirus infections are associated with acute diarrhea that may lead to dehydration and occasionally death. Rotaviruses cause an estimated 20 to $40 \%$ of the hospitalizations associated with diarrhea in children and an estimated 870000 deaths per year, primarily in developing countries (3). Even in an industrialized country such as the United States, where mortality from rotavirus diarrhea is relatively low (20-40 deaths per year), morbidity is high. Specifically, about 55000 children are hospitalized for rotavirus diarrhea each year in the U.S., and the disease is estimated to cost US\$ 1.4 billion in medical and indirect expenses (4).

Early epidemiologic studies suggested that rotaviruses might be controlled using vaccines. Longitudinal surveys demonstrated natural immunity; children infected more than once had less severe symptoms on reinfection (5-7); and newborns acquired protection that lasted for several years $(8,9)$. However, the immunity derived from natural infection is not fully protective, and seropositive adults may develop rotavirus diarrhea while caring for sick children or traveling in developing countries where enteric infections are common (10).

The development of a rotavirus vaccine was facilitated by the discovery of methods for growing human rotavirus in tissue culture (11). Several live attenuated vaccines have been developed, and two live oral vaccines are being tested in field studies $(12,13)$. Once licensed, they will be considered for use in the routine immunization schedule of children in the United States. Within this context, a new vaccine could bring a dramatic decline in the number of hospitalizations and medical visits arising from childhood diarrhea and could reduce the num- bers of diarrhea-associated deaths in developing countries.

In Argentina, rotavirus was first reported as a cause of childhood gastroenteritis in 1975, when Lombardi et al. detected rotavirus in 20 diarrheal disease specimens examined by electron microscopy (14). In 1978, Muchinik et al. conducted the first study to determine the frequency of rotavirus in patients with acute diarrhea admitted to the "Ricardo Gutiérrez" Children's Hospital of Buenos Aires (15-17). Since then, a variety of other studies developed by several groups have evaluated different aspects of rotavirus epidemiology in different settings (17-35).

In 1995, the Argentine Society of Virology organized a viral gastroenteritis workshop at the "Dr. Carlos G. Malbrán" National Institute of Microbiology to examine the rotavirus disease burden, evaluate what should be done, and propose new strategies for future control. This workshop recommended organizing what became known as the Viral Diarrhea Study Group to review all available published and unpublished information about rotavirus epidemiology in Argentina and to conduct a nationwide survey of rotavirus diarrhea using standardized diagnostic methods and a common study design. This article provides an initial review of studies already conducted in Argentina-a review seeking to examine rotavirus diarrhea epidemiology, assess the disease burden, and identify improved methods for monitoring such epidemiology in the event a vaccine program is considered for national use.

\section{METHODOLOGY}

We reviewed data from 17 studies conducted in six Argentine cities (Avellaneda, Buenos Aires, Córdoba, La Plata, Mendoza, and Tucumán); "point observations" in three citiesdescriptions of non-group A rotaviruses in Resistencia and Posadas (19, 34) and a five-month epidemiologic study in Jujuy (36); and data from a multicenter project (37) conducted in the cities of Buenos Aires, Córdoba, La Plata, Mar del Plata, Posadas, Rosario, and Tucumán (see Figure 1 and Table 1). The latter multicenter study, which was designed to survey bacterial diarrheas, provided results on human rotavirus epidemiology that contrasted with the other findings analyzed.

In most of the epidemiologic studies reviewed, rotavirus was detected using enzyme immunoassays (EIAs) $(21-26,29,30,35,38)$ or viral RNA analysis employing polyacrylamide gel electrophoresis (PAGE) (18-20, 25-34, 36, 39). The PAGE procedures used were similar in all the studies and had a sensitivity comparable to that of EIA, yielding positive results with $92 \%$ (26) and $100 \%$ (32) of the samples found positive by EIA. Laboratories involved in the multicenter study (37) used various different rotavirus detection methods (PAGE, enzyme-linked immunosorbent assay [ELISA], and latex agglutination) for rotavirus detection. The early studies of Muchinik et al. (15-17) used electron microscopy and counterimmunoelectrophoresis, which are slightly less sensitive than EIA and PAGE.

We reviewed the various studies to identify annual and seasonal trends in rotavirus detection, differences in detection rates among hospitalized and nonhospitalized populations, and the age distributions of disease patients. We also used composite hospitalization and outpatient visit data to estimate the disease burden of rotavirus diarrhea in Argentina and the cost of the disease to the health care system. In several laboratory studies, the prevalent G-serotypes of group A rotavirus were identified by using a monoclonalbased EIA described previously (40). Group C rotavirus, an antigenically distinct strain with different epidemiologic features, was reported from four centers where PAGE was used as the routine diagnostic test.

\section{RESULTS}

Of the 17 studies reviewed, 10 involved patients hospitalized for diarrhea, six targeted patients seen as 
FIGURE 1. Rates of rotavirus detection in Argentina reported by some of the studies listed in Table 1 for children with diarrhea (including studies of hospitalized cases, nonhospitalized cases, and combinations of the two)

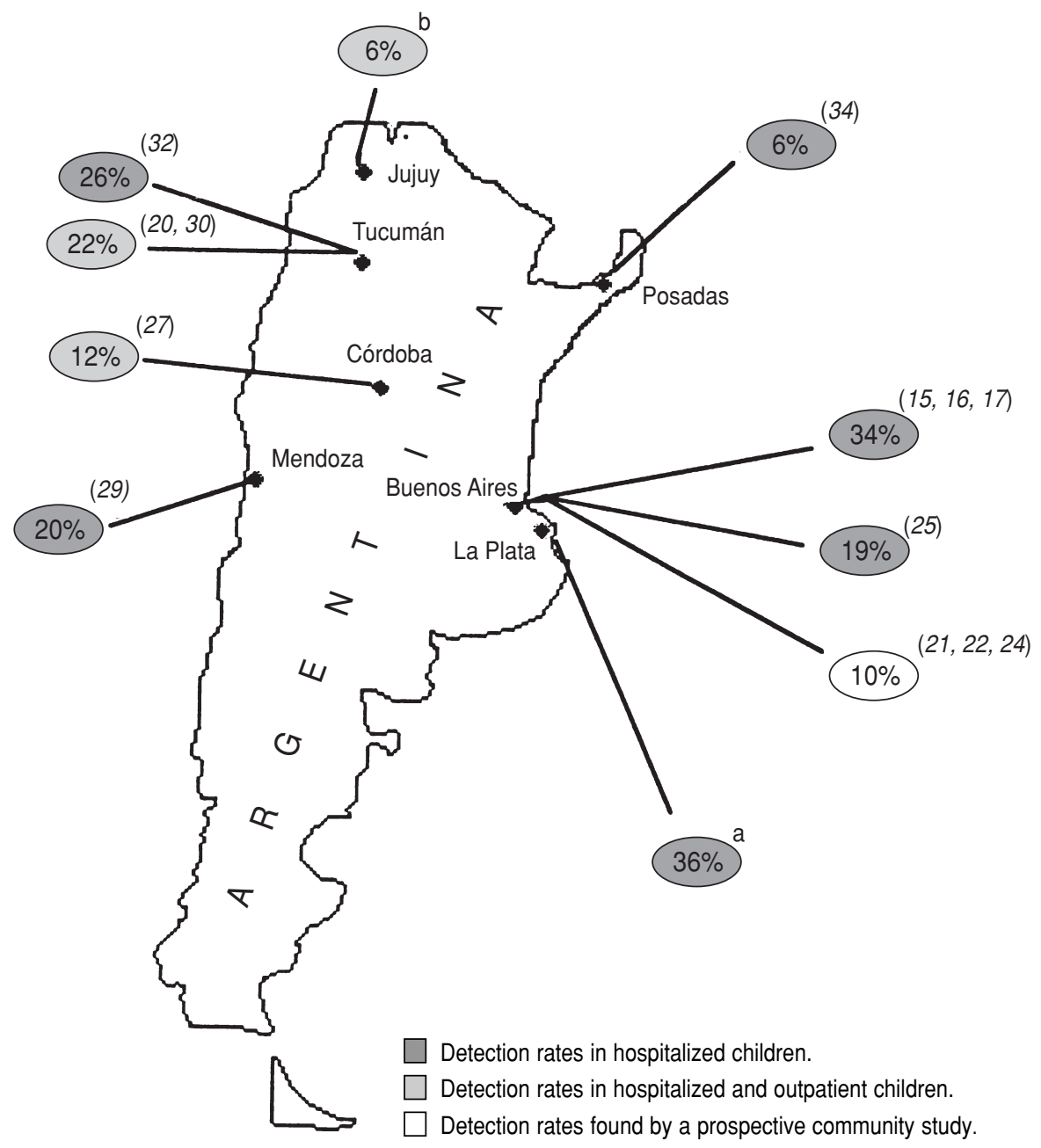

a Borsa A, personal communication, July 1995.

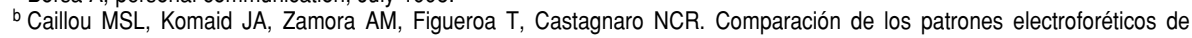
rotavirus detectados en Tucumán y Jujuy. Unpublished report, 1991.

outpatients or as part of mixed (hospitalized and outpatient) populations, and one examined the prevalence of rotavirus infection in asymptomatic newborns (Table 1). Only two of these studies carried out surveillance for more than 3 years and received samples from both hospitalized and outpatient children $(20,27)$. One study reported the monthly frequency of rotavirus identification (20). The single study of asymptomatic newborns identified rotavirus in $3 \%$ of 304 infants born at a maternity hospital in Tucumán between May and October 1990 (32).

\section{Rotavirus in hospitalized children}

As Table 1 indicates, 10 studies reported the frequency with which rotavirus was detected in children hospitalized for diarrhea $(14-17,25,29,31$, $32,34,35,37,38)$. The median rate of rotavirus detection was $20 \%(95 \% \mathrm{CI}$ :
$14 \%-34 \%$ ), with the figures from individual studies ranging from $6 \%$ to $54 \%$. The two unpublished reports found annual frequencies of $11 \%$ (37) and $36 \%(38)$. The different detection rates were not clearly associated with different detection methods employed in the studies.

\section{Rotavirus in other children}

A total of six studies examined the frequency of rotavirus in diarrhea outpatients or community members. Two of these examined the frequency of rotavirus diarrhea among pediatric outpatients $(35,37)$; three others dealt with mixed populations of hospitalized and outpatient children with diarrhea $(20,27,30,33,36)$; and one was a prospective community-based study performed in the city of Avellaneda, which is located $15 \mathrm{~km}$ south of Buenos Aires (21, 22, 24).

The multicenter study by Binstein and colleagues (unpublished) was specifically designed to identify bacterial causes of diarrhea, but rotavirus was detected in $11 \%$ of the fecal specimens obtained from the more than 4000 cases examined between 1986 and 1989. The other study reporting pediatric outpatient data (and which kept these data separate from those for hospitalized children) sought to identify all the recognized diarrhea pathogens of patients seen at the Buenos Aires Children's Hospital during the summer season. This study found rotavirus in $7 \%$ of the outpatients and $20 \%$ of the hospitalized children studied (35).

The three studies of mixed populations (including both outpatients and hospitalized children) detected rotavirus in $22 \%(20), 12 \%(27)$, and $6 \%$ (36) of the children studied.

Finally, the community-based study in Avellaneda identified rotavirus in $10 \%$ of the study patients with acute diarrhea $(21,22,24)$.

The median rate of rotavirus detection in the heterogeneous groups examined by these six studies was $10.5 \%(95 \%$ CI: $5 \%-17 \%)$, the rates found by the different studies ranging 
TABLE 1. Epidemiologic studies of childhood rotavirus in Argentina, showing the type of subjects tested (hospitalized or nonhospitalized, with or without diarrhea), the city and year of the study, the age range of the subjects, the test used to detect rotavirus, the number of samples tested, and the number and percentage found positive for rotavirus

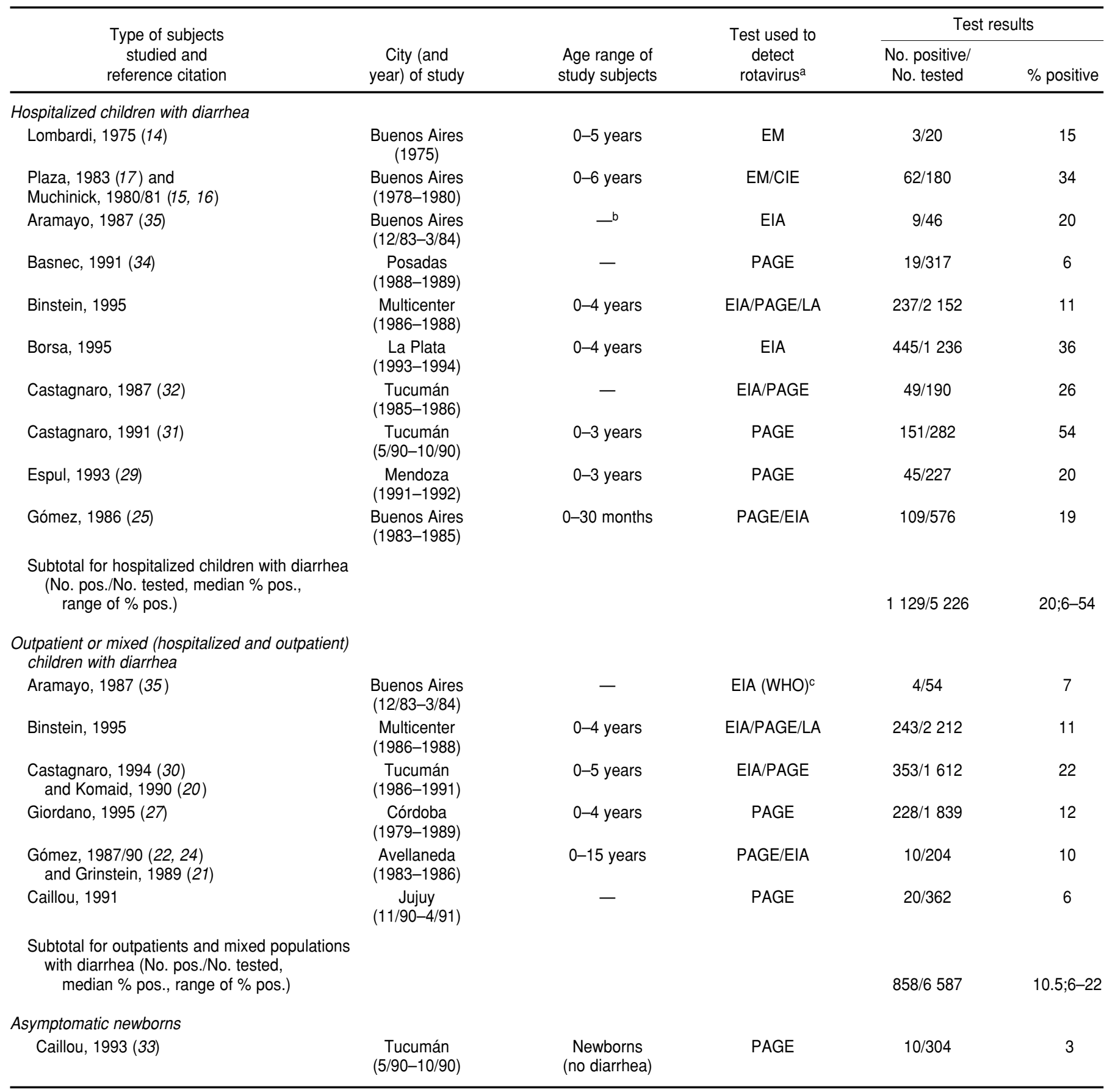

\footnotetext{
a $\mathrm{EM}$ = electron microscopy; $\mathrm{CIE}$ = counterimmunoelectrophoresis; $\mathrm{EIA}$ = enzyme immunoassay; PAGE = polyacrylamide gel electrophoresis; $\mathrm{LA}=$ latex agglutination . $b_{-}=$data not available.

${ }^{c}$ The ELISA formulated and distributed by the World Health Organization Collaborating Center for Reference and Research on Rotavirus, Birmingham, U.K.
}

from 6 to $22 \%$ (see Table 1). Overall, these results suggest a lower percentage of rotavirus-associated diarrheas in nonhospitalized study populations than in hospitalized ones.

\section{Seasonal trends}

The seasonality of rotavirus diarrhea was examined by three of the studies conducted for 2 years or more
(Figure 2a). Rotavirus was detected in the highest percentages of diarrhea patients during the cold May-July period $(20,21,24,25)$, when it was sometimes identified in more than 
FIGURE 2. Data on the seasonality of diarrhea and rotavirus diarrhea in Argentina indicating that diarrhea episodes have tended to peak in the summer months while the share of cases caused by rotavirus has tended to peak in the winter months
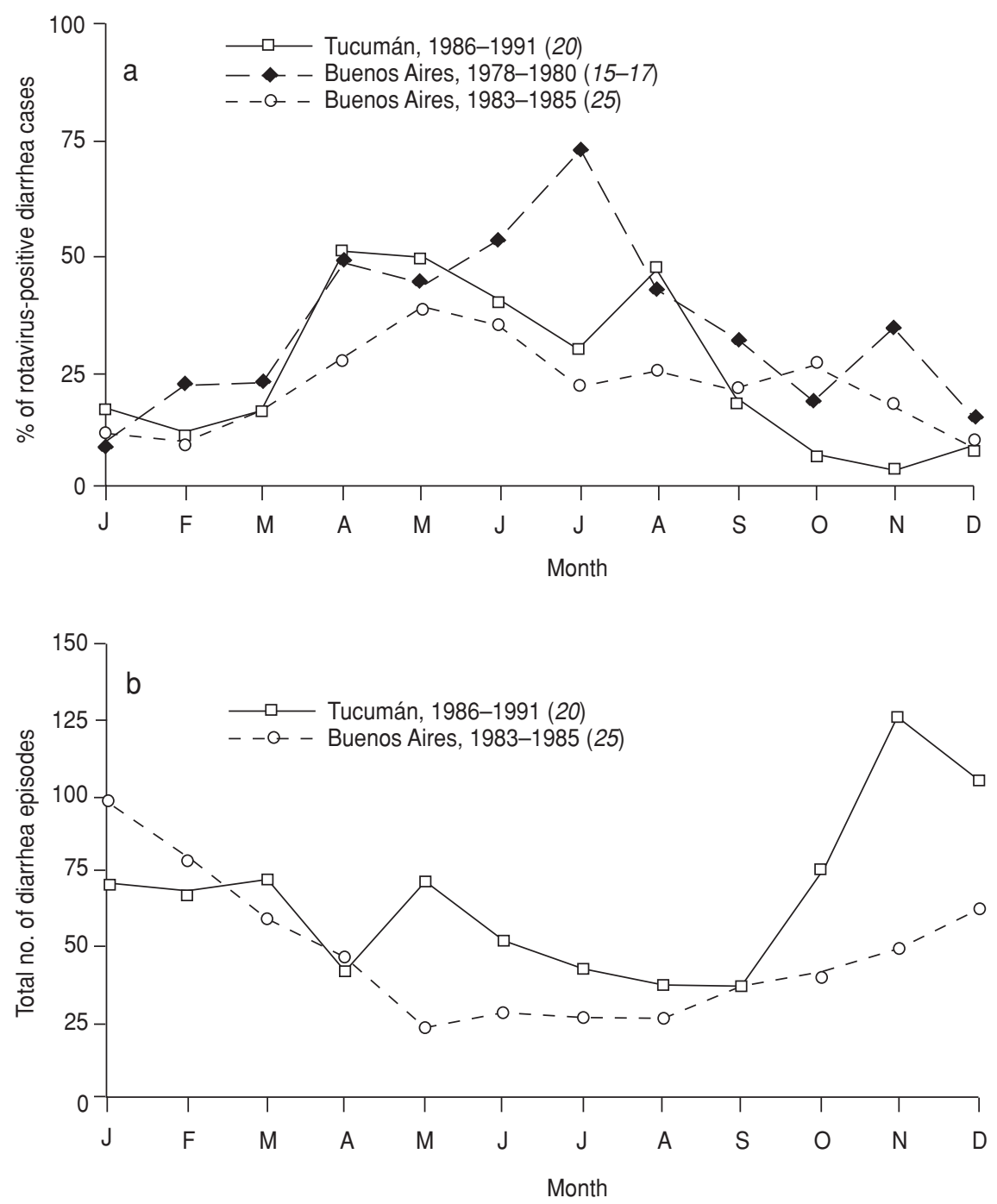

$50 \%$ of all children hospitalized for diarrhea $(15-17,31,32)$. In both Buenos Aires and Tucumán, the winter peak of rotavirus detections occurred when the total number of diarrhea cases was relatively low; the peak numbers of diarrhea cases, most of bacterial origin, occurred in the summer months (Figure 2b) (21).

A prospective study of diarrhea in children conducted in Avellaneda, near Buenos Aires, demonstrated that the incidence of rotavirus-associated diarrhea was significantly higher dur( 3 cases per 1000 person-months) (21, 24). Although the peak in the percentage of diarrhea cases associated with rotavirus is surely influenced by the decreased numbers of diarrhea cases observed in the winter months, the two studies providing detailed information for several years also found the peak numbers of rotavirus cases to have occurred in the winter months of May and June $(20,21,24)$.

\section{Patient age}

While rotavirus commonly causes diarrhea in children 6-24 months of age worldwide, it appears that Argentine children tend to develop rotavirus diarrhea relatively young (Figure 3). A number of investigators reported that $80 \%$ of the rotavirus cases were detected during the first year of life, and that $35 \%$ had occurred by 6 months of age $(17,21,24)$. On the other hand, the unpublished multicenter study by Binstein and colleagues noted no decline in rotavirus diarrhea detection rates between birth and 4 years of age.

\section{Rotavirus serotypes}

A total of 294 rotavirus strains from three separate specimen collections were subjected to ELISA serotyping for G-protein (i.e., the outer capsid viral protein VP7) (Table 2). Of the 294 strains, 123 were collected in Buenos Aires (1983-1985) (23), 126 were obtained in Tucumán (1986-1991) (30), and 45 were obtained in Mendoza (1991-1992) (29). Not all of the sample strains could be serotyped, but of the $230(78 \%)$ that were, $137(60 \%)$ corresponded to the G1 serotype, $46(20 \%)$ corresponded to the G2 serotype, 32 $(14 \%)$ corresponded to G4, $11(5 \%)$ corresponded to G3, and $4(2 \%)$ corresponded to non G1-G4. As the table indicates, all but one of the typed Men-

FIGURE 3. Distributions of rotavirus diarrhea by age that were reported by studies in Tucumán (31), Avellaneda (21, 22, 24), and Buenos Aires (15-17)

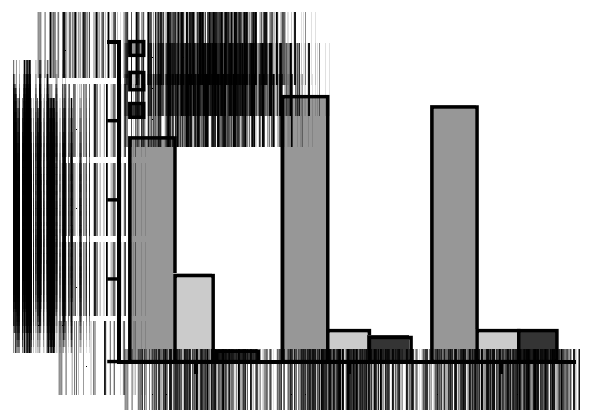


TABLE 2. Serotyping of rotavirus strains in Argentina

\begin{tabular}{|c|c|c|c|c|c|c|c|c|}
\hline \multirow[b]{2}{*}{ Reference } & \multirow[b]{2}{*}{ City of study } & \multirow[b]{2}{*}{ Years of study } & \multirow{2}{*}{$\begin{array}{l}\text { No. of samples } \\
\text { studied/serotyped }\end{array}$} & \multicolumn{5}{|c|}{ Serotypes identified } \\
\hline & & & & G1 & G2 & G3 & G4 & non G1-G4 \\
\hline Gómez (23) & Buenos Aires & $1983-1985$ & $123 / 73$ & 28 & 13 & 10 & 18 & 4 \\
\hline Castagnaro (30) & Tucumán & $1986-1991$ & $126 / 114$ & 67 & 33 & - & 14 & - \\
\hline Total & & 1983-1992 & $294 / 230$ & 137 & 46 & 11 & 32 & 4 \\
\hline
\end{tabular}

doza strains were G1, and no G3 strains were found in the Tucumán samples.

The Buenos Aires study was the only one that used monoclonal antibody directed at a common antigen on VP7 in addition to four serotyping monoclonal antibodies. In 46 of the 50 Buenos Aires samples that could not be serotyped, the specimen exhibited no reactivity to the former antibody, suggesting that failure to serotype was due to degradation of the specimen. Three of the remaining four specimens that could not be serotyped exhibited reactivity to more than one of the four serotyping monoclonal antibodies, while the last specimen responded negatively to all four of these antibodies. No analysis has been performed on the $\mathrm{P}$ serotypes of strains from Argentina.

\section{Group C rotavirus}

Seven group $C$ rotavirus strains were identified by PAGE from specimens collected in Resistencia (19), Posadas (34), Tucumán (18), and Buenos Aires (39). However, none of them has been confirmed with reagents specific for Group C rotavirus. This chance finding in specimens from four separate locations indicates that Group C rotaviruses may be widely distributed in Argentina, even though no information about their prevalence is available.

\section{Cost analysis}

We estimated the total number of rotavirus-associated diarrhea cases per year in Argentina, as well as the numbers involving outpatient treatment and hospitalization, in order to determine the approximate national costs of rotavirus diarrhea (Table 3 and Figure 4). The size of the cohort of at-risk children was estimated from the 1991 National Census of Population and Housing (41). The percentage of hospitalized rotavirus-associated diarrhea cases was estimated from the study conducted at the Buenos Aires Children's Hospital (25) and from data in the foregoing analysis. Epidemiologic data on the incidence of all diarrheas, rotavirus diarrheas, and diarrhea cases requiring hospitalization or medical attention were obtained from the prospective study performed in Avellaneda (21, 22, 24).

Using an estimated diarrhea incidence of 2.1 cases per child-year among Argentine children 0-23 months old, a hospitalization rate of $3.9 \%(21,22,24)$ for these cases, and a rotavirus detection rate of $19 \%$ among children hospitalized for diarrhea (25), we estimated

TABLE 3. Estimated cost and annual disease burden of rotavirus diarrhea in Argentina

\begin{tabular}{|c|c|c|}
\hline & No. & $\begin{array}{l}\text { Risk per child } \\
0-23 \text { months old }\end{array}$ \\
\hline Births & 650000 & \\
\hline Episodes of rotavirus gastroenteritis & 169000 & $1 / 4$ \\
\hline Outpatient cases seen & 84500 & $1 / 8$ \\
\hline Hospitalizations & 21000 & $1 / 31$ \\
\hline \multicolumn{3}{|l|}{ Cost of } \\
\hline Hospitalization $^{a}$ & US\$25.2 million & \\
\hline Outpatient care ${ }^{b}$ & US\$ 2.5 million & \\
\hline Total direct medical care & US\$27.7 million & \\
\hline
\end{tabular}

a Estimating the average hospital stay to last four days at a cost of US $\$ 300$ per day.

${ }^{b}$ Estimating the average treatment cost to be US $\$ 30$ per case. that 21000 of the 650000 Argentine children born in 1991 would be hospitalized for rotavirus-associated diarrhea during their first two years of life.

Looking at the situation slightly differently, we estimated the incidence of rotavirus-associated diarrheas at 0.13 cases per child-year among Argentine children 0-23 months old $(21,22,24)$, the proportion of afflicted children seeking medical attention at $50 \%$, and the proportion requiring hospitalization at $12.5 \%(21,22,24)$. On this basis, we estimated the annual number of rotavirus diarrhea cases at 169000 and the number of cases seeking medical attention at 84500 . In other words, according to these calculations about one in four Argentine children develops rotavirus diarrhea, one in eight seeks medical attention for it, and one in 31 is hospitalized for it during the first two years of life.

The average cost of hospitalization was estimated at US\$ 300 per day, an estimate based on the rates that two hospitals (the Children's Hospital of
US\$ 2.5 million 
FIGURE 4. Estimated numbers of diarrheal episodes, hospitalized diarrhea cases, rotavirus diarrhea episodes, rotavirus cases receiving medical care, and hospitalized rotavirus cases among Argentine children less than two years old

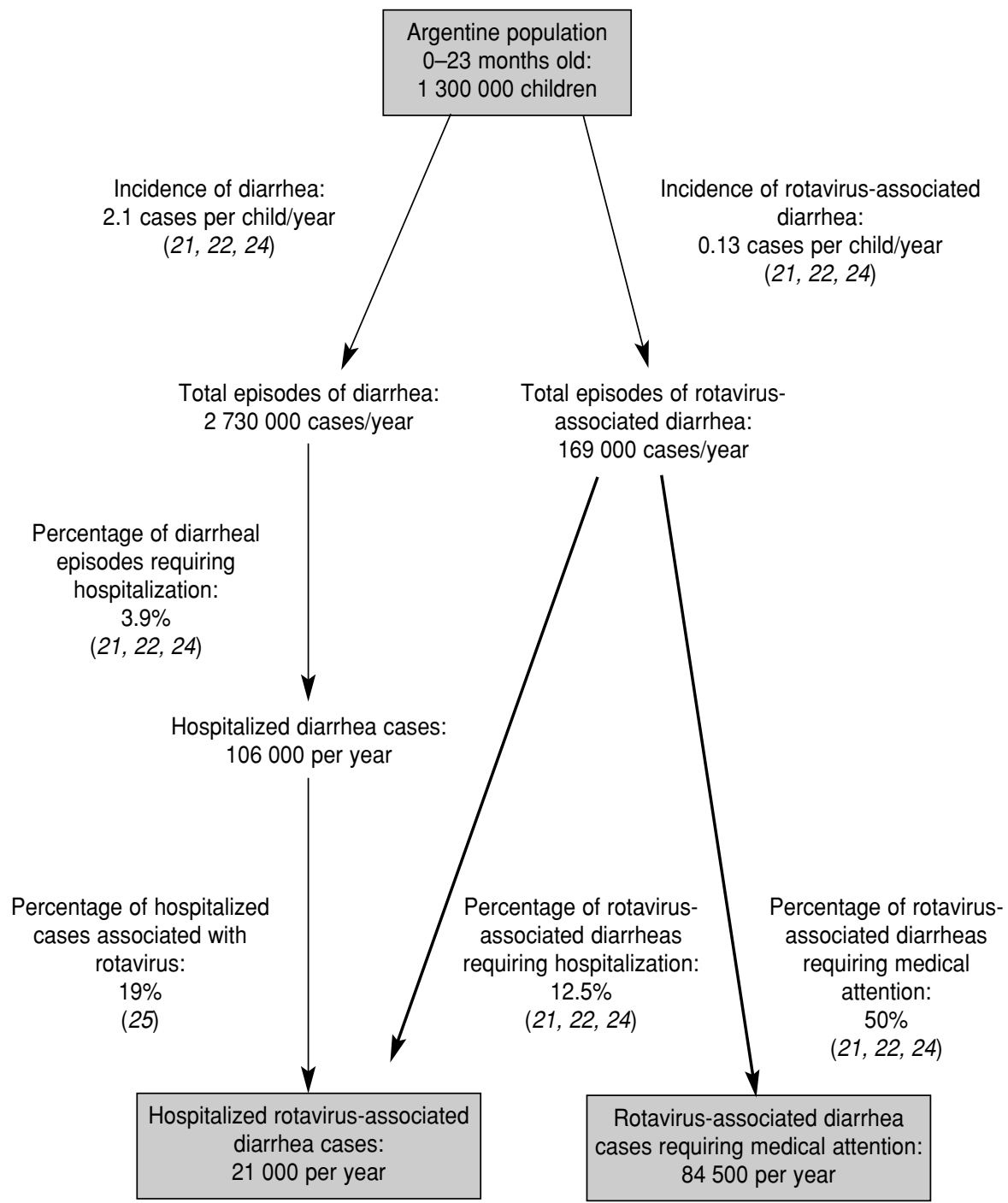

Córdoba and the "Ricardo Gutiérrez" Children's Hospital of Buenos Aires) are charging Argentina's National Health Insurance Services. The average cost of caring for children seen as outpatients for rotavirus-associated diarrhea was estimated at US\$ 30 per case, based on the average cost of a doctor or clinic visit, plus transportation and parent/guardian time lost from work. Applying the estimated daily hospitalization cost of US\$300, together with an estimated average hospital stay length of four days and den and research needs, with an eye to assessing a vaccine's potential usefulness in our country. The studies reviewed indicate that rotavirus is the most common single cause of severe childhood diarrhea in Argentina, it being detected in a median of $20 \%$ of the children hospitalized for diarrhea. In general, rotavirus tended to be associated with relatively severe diarrheal disease cases and was found more commonly among children hospitalized with diarrhea than among those seen as outpatients or included in community studies. Based on the few studies available, we estimated that of the 650000 children born in Argentina in 1991, one in eight (84 500) sought medical care and one in 31 (21 000) was hospitalized for rotavirus diarrhea. Lacking any specific study on the cost of rotavirus diarrhea, we made a rough estimate indicating that medical costs of the disease in Argentina exceed US\$ 27 million per year. Overall, it appears that introduction of an effective rotavirus vaccine into the national childhood immunization program could substantially decrease the rotavirus disease burden and might well prove worthwhile if the vaccine's cost was not excessive. Obviously, a costeffectiveness study would help planners arrive at a decision.

We identified several features of rotavirus diarrhea in Argentina relating to seasonality and patient age that differed from those normally expected in a developed country located in a temperate climate.

Regarding seasonality, although the virus was detected year-round, the peak levels of rotavirus detection occurred in winter (May-July), when rotavirus was found in some $50 \%$ of the study children hospitalized for diarrhea. This contrasts with the apparent situation in the United States, where peak rotavirus detection coincides with the summer peak in diarrhea hospitalizations. However, a recent U.S. investigation of numerous apparent rotavirus infections identified during the summer months found that many of these diagnoses could be explained by false-positive laboratory results (42). Further determination as 
to whether many of these summer cases were or were not due to rotavirus infection would help to clarify whether the difference observed between the U.S. and Argentine patterns derives from more even year-round U.S. transmission or laboratory error.

In Mexico, a change from a summer to a winter peak in childhood diarrheal deaths has been associated with major national efforts to control cholera and other bacterial diarrheas through actions such as chlorination of water sources (43). Further studies directed at shedding light on this subject might productively examine whether summer peaks in the incidence of bacterial diarrhea differ greatly among people of lower versus upper socioeconomic status in a country with low infant mortality such as Argentina.

This review found that Argentine children appeared to be infected with rotavirus at an earlier age than children in other developed countries. The available data indicate that more than $80 \%$ of the cases occurred in the first year of life, with 35\% occurring in the first six months. This patient age distribution, which was younger than that found in other temperate, developed country settings, may be associated with year-round transmission of infection. Because of this age factor, a rotavirus vaccine might have to be delivered earlier, perhaps through administration of a neonatal dose. Also, the duration of protection might only need to be one year, and the maximum impact of a control program could be measured within the first year of the intervention.

The studies reviewed here had many limitations, and the insights they have provided need to be reaffirmed. The wide range of detection rates recorded by hospital surveys could be due to various factorsincluding seasonality, the age distribution of the study subjects, the severity of their disease, and the sensitivity of the assays used. The absence of any common screening criteria for these studies precluded looking for geographic or temporal trends that could be of considerable interest. Finally, it should be noted that the disease burden estimates presented here represent a preliminary "guess" at the magnitude of the problem. These estimates have been derived from a small number of surveys that have not encompassed the whole nation. The estimates also need to be improved by using national data for the numbers of child hospitalizations and deaths from diarrhea-data that were not available for this analysis. These national data would provide important points of reference, as similar national data have for studies in the United States and the United Kingdom $(4,44)$.

As a result of the review reported here, a national sentinel hospital surveillance program has begun in six Argentine cities. The participating centers are using a common case definition, collecting comparable epidemiologic data, and assessing fecal specimens with a common assay that will be controlled for quality by the Na- tional Reference Laboratory. The data obtained should play a critical role in developing better estimates of the cost-effectiveness of a rotavirus vaccine intervention program and in better understanding the observed peculiarities of rotavirus epidemiology in Argentina. The program's data may also prove critical in deciding whether to introduce a rotavirus vaccine into routine childhood immunizations and would certainly help in monitoring the effects of such immunization in the event that this were done.

Acknowledgments. The members of the Viral Diarrheal Study Group are Nelda R. De Castagnaro and José A. Komaid (Institute of Microbiology, Biochemistry Faculty, National University of Tucumán), Carlos Espul and Hector Cuello (Virology Laboratory, Central Hospital of Mendoza), Jorge A. Gómez and Karin Bok (Viral Gastroenteritis Laboratory, Department of Virology, National Institute of Infectious Diseases, National Ministry of Health and Social Action), Miguel O. Giordano and Silvia Nates (Institute of Virology, "Dr. J. M. Vanella" Faculty of Medical Sciences, National University of Córdoba), Ana Borsa (Virology Laboratory, Children's Hospital of La Plata), Saul Grinstein (Virology Laboratory, "Ricardo Gutiérrez" Children's Hospital of Buenos Aires), and Isabel Miceli (Bureau of Epidemiology, National Ministry of Health and Social Action).

\section{REFERENCES}

1. World Bank. World Bank Development Report 1993: Investing in Health. New York: Oxford University Press; 1993:329.

2. Bishop RF, Davidson GP, Holmes IH, Ruck BJ. Virus particles in epithelial cells of duodenal mucosa from children with viral gastroenteritis. Lancet 1973;1:1281-1283.

3. De Zoysa I, Feachem RV. Intervention for the control of diarrhoeal diseases among young children: rotavirus and cholera immunization. Bull World Health Organ 1985;63: 569-583.
4. Glass RI, Kilgore PE, Holman RC, Jin S, Smit JC, Woods PA, et al. The epidemiology of rotavirus diarrhea in the United States: surveillance and estimates of disease burden. $J$ Infect Dis 1996;174(suppl 1):S5-11. (Presented at the 5th Rotavirus Vaccine Workshop, Atlanta, Georgia, 16-17 October 1995).

5. Ward RL, Bernstein DI, for the US Rotavirus Vaccine Efficacy Group. Protection against rotavirus disease after natural rotavirus infection. J Infect Dis 1994;169:900-904.
6. Bernstein DI, Sander DS, Smith VE, Schiff GM, Ward RL. Protection from rotavirus reinfection: 2-year prospective study. J Infect Dis 1991;164:277-283.

7. Velázquez FR, Matson DO, Calva JJ, Guerrero ML, Morrow AL, Carter-Campbell S, et al. Rotavirus infection in infants as protection against subsequent infections. $N$ Engl J Med 1996;335:1022-1028.

8. Bishop RF, Barnes GL, Cipriani E, Lund JS. Clinical immunity after neonatal rotavirus 
infection: a prospective longitudinal study in young children. N Engl J Med 1983;309: 72-76.

9. Bhan MK, Lew JF, Sazawal S, Das BK, Gentsch JR, Glass RI. Protection conferred by neonatal rotavirus infection against subsequent diarrhea. J Infect Dis 1993;168:282-287.

10. Hardy D. Epidemiology of rotaviral infection in adults. Rev Infect Dis 1987;9:461-469.

11. Wyatt RG, James WD, Bohl EH, Theil KW, Saif LJ, Kalica AR, et al. Human rotavirus type 2: cultivation in vitro. Science 1980;207:189-191.

12. Kapikian AZ, Vesikari T, Ruuska T, Madore HP, Christy C, Dolin R, et al. An update on the "Jennerian" and modified "Jennerian" approach to vaccination of infants and young children against rotavirus disease. Adv Exp Med Biol 1992;327:59-69.

13. Clark HF, Offit PA, Ellis RW, Eiden JJ, Krah D, Shaw AR, et al. The development of multivalent bovine rotavirus (strain WC3) reassortant vaccine for infants. J Infect Dis 1996;174(suppl 1):S73-80.

14. Lombardi GH, Roseto AM, Stamboulian D, Barrera Oro JG. Virus of infantile gastroenteritis in Argentina. Lancet 1975;2:1311-1314.

15. Muchinik GR, Grinstein S. Rotavirus infection in children hospitalized for diarrhoea in Argentina. Ann Trop Paediatr 1980;1:167-173.

16. Muchinik GR, Grinstein S. Rotavirus in Buenos Aires, Argentina. Intervirology 1980; 13:253-256.

17. Plaza A, Grinstein S, Muchinik G, Valvano M, Gómez JA. Estudio clínico y epidemiológico de la diarrea por rotavirus en la infancia. Arch Argent Pediatr 1982;80:289-308.

18. Komaid JA, Caillou MSL, Suárez AM, Zamora AM, Castagnaro NR. Detección de rotavirus no-A en Tucumán. Rev Argent Microbiol 1991; 23:172-174.

19. Sorrentino A, Schodeller EA, Bellinzoni R, Muchinik G, La Torre JL. Detection of an atypical rotavirus associated with diarrhoea in Chaco, Argentina. Trans $R$ Soc Trop Med Hyg 1986;80:120-122.

20. Komaid JA, Caillou SL, Suárez AM, Castagnaro N. Electroserotipos del ARN de rotavirus durante cuatro años de estudio de gastroenteritis en Tucumán. Rev Argent Microbiol 1990;22:123-129.

21. Grinstein S, Gómez JA, Bercovich JA, Biscotti EL. Epidemiology of rotavirus infection and gastroenteritis in prospectively monitored Argentine families with young children. Am J Epidemiol 1989;130:300-308.

22. Gómez J, Bercovich A, Álvarez A, Garrido D, Grinstein S. Seroepidemiology of human rotaviruses in a community of the Avellaneda
District, Province of Buenos Aires. Rev Argent Microbiol 1990;22:182-191.

23. Gómez J, Estes MK, Matson DO, Bellinzoni R, Álvarez A, Grinstein S. Serotyping of human rotaviruses in Argentina by ELISA with monoclonal antibodies. Arch Virol 1990;112: 249-259.

24. Gómez JA, Bercovich J, Biscotti E, Siniawski S, Sternberg L, Montesi A, et al. Diarrea por rotavirus: estudio prospectivo de 49 familias del partido de Avellaneda, provincia de Buenos Aires. Arch Argent Pediatr 1987;85: 139-149.

25. Gómez JA, Biscotti EL, Bercovich JA, Grinstein S. Epidemiology of human rotaviruses in Argentina as determined by RNA genome electrophoresis. Intervirology 1986;26:174-180.

26. Gómez JA, Bercovich JA, Grinstein S. Comparison of enzyme immunoassay, counterimmunoelectrophoresis, and polyacrylamide gel electrophoresis for the diagnosis of rotaviruses. Rev Argent Microbiol 1985;17:111-114.

27. Giordano MO, Depetris AR, Nates SV. Estudio retrospectivo de la circulación de electroserotipos de rotavirus humano en la ciudad de Córdoba, Argentina, 1979-1989. Rev Argent Microbiol 1995;27:1-10.

28. Giordano MO, Basnec SN, Nates SV, Bennun F, Depetris AR. Rapid techniques for diagnostic and epidemiologic studies of rotavirus infection. J Virol Methods 1991;35:59-63.

29. Espul C, Cuello H, Navarta LM, Mamani N, O'Ryan M. Characterization of antigenic types of circulating rotaviruses in Mendoza, Argentina, based on typing of the external VP7 capsid protein. Acta Gastroenterol Latinoam 1993;23:211-216.

30. Castagnaro NCR, Komaid JA, Caillou MSL, Zamora AM, Naval MSM, Suárez AM. Variación temporal de electroserotipos y serotipos de rotavirus humanos en el noroeste argentino. Acta Bioquim Clin Latinoam 1994;28: 385-391.

31. Castagnaro NR, Caillou SL, Komaid JA, Díaz $\mathrm{N}$, Suárez AM, Zamora AM. Infección rotaviral detectada en la sala de hidratación del Hospital del Niño Jesús. Cienc Med 1991;6: 27-33.

32. Castagnaro NR, Komaid JA, Suárez AM, López de Caillou S, Raya JM. Detección de rotavirus (RV) en casos de gastroenteritis infantil (GEI) en Tucumán: comparación de las técnicas de enzimoinmunoensayo (ELISA) y electroforesis del RNA vírico (PAGE). Rev Fac Med Tucumán 1987;19:3-5.

33. Caillou SL, Komaid JA, Suárez A, Castagnaro $\mathrm{AE}$, Zamora A, Castagnaro NR. Búsqueda de rotavirus en neonatos. Cienc Med 1993;8: 319-325.

34. Basnec SN, Giordano MO, Bennun FR, Nates SV, Vergara M, Depetris AR. Detection of two atypical rotaviruses in the province of $\mathrm{Mi}$ siones, Argentina. Acta Virol 1991;35:408-412.

35. Aramayo I, Galanternik L, Botto L, Elldid ME, Gómez JA, Grinstein S, et al. Agentes patógenos entéricos aislados en niños con diarrea aguda asistidos en el Hospital de Niños "Ricardo Gutiérrez." Arch Argent Pediatr 1987; 85:181-189.

36. Caillou MSL, Komaid JA, Zamora AM, Figueroa T, Castagnero NCR. Comparación de los patrones electroforéticos de rotavirus detectados en Tucumán y Jujuy. Universidad de Tucumán. [Unpublished report]. 1991.

37. Binstein N. Instituto Nacional de Enfermedades Infecciosas. [Unpublished data]. 1995.

38. Borsa A. Laboratorio de Virología, Hospital de Niños de la Plata. [Unpublished data]. 1995.

39. Gómez JA. [Unpublished data]. 1991.

40. Taniguchi K, Urasawa T, Morita Y, Greenberg $\mathrm{HB}$, Urasawa S. Direct serotyping of human rotavirus in stools using serotype 1-, 2-, 3-, and 4-specific monoclonal antibodies to VP7. J Infect Dis 1987;155:1159-1166.

41. Instituto Nacional de Estadística y Censos. Censo Nacional de población y vivienda. Buenos Aires: INDEC; 1991:101.

42. LeBaron CW, Allen JR, Hebert M, Woods PA, Lew JF, Glass RI, and participating laboratories in the National Rotavirus Surveillance System. Outbreaks of summer rotavirus linked to laboratory practices. Pediatr Infect Dis J 1992;11:860-865.

43. Gutiérrez G, Tapia-Conyer R, Guiscafré H, Reyes $\mathrm{H}$, Martínez $\mathrm{H}$, Kumate J. Impact of oral rehydration and selected public health interventions on reduction of mortality from childhood diarrheal diseases in Mexico. Bull World Health Organ 1996;74:189-197.

44. Ryan MJ, Ramsay M, Brown D, Gay NJ, Farrington $\mathrm{CP}$, Wall PG. Hospital admissions attributable to rotavirus infection in England and Wales. I Infect Dis 1996;174(suppl 1): S12-18.

Manuscript received on 4 November 1996. Revised version accepted for publication on 20 August 1997. 
RESUMEN En todo el mundo, los rotavirus son la causa más común de diarrea grave en los niños pequeños y actualmente se están ensayando sobre el terreno vacunas que posiblemente permitan inmunizar a la población infantil dentro de varios años. Con el fin de

\section{En anticipación de una vacuna antirrotavirus: revisión de estudios epidemiológicos sobre la diarrea por rotavirus en la Argentina}

estimar la carga de enfermedad por rotavirus en la Argentina y la utilidad de establecer en el país un sistema de vigilancia de la enfermedad, se revisaron datos sobre la detección de estos virus, según estudios publicados y otros inéditos de nueve ciudades argentinas y uno multicéntrico. Los informes revisados indican que se detectaron rotavirus en $20 \%$ de 5226 especímenes (con un recorrido de 6 a $54 \%$ entre estudios) tomados de niños hospitalizados por diarrea y en $9 \%$ de 6587 especímenes (recorrido de 5 a $22 \%$ entre estudios) tomados de pacientes ambulatorios, miembros de poblaciones mixtas (niños hospitalizados y ambulatorios) y sujetos sometidos a encuestas comunitarias. Los datos correspondientes a hospitales muestran que, si bien los virus se detectaron durante todo el año, en los meses de invierno (mayo a julio) hubo un pico de intensidad cuando hasta la mitad de los niños con diarrea tuvieron resultados positivos a los rotavirus. En tres laboratorios se logró serotipificar para la proteína G a 230 de 294 especímenes positivos (78\%); los resultados indican que el serotipo G1 fue el más común (presente en $60 \%$ de los especímenes serotipificados), seguido del G2 (en 20\%), G4 (en 14\%) y G3 (en 5\%). Sobre la base de los datos obtenidos en el país, se estimó que en 1991 en la Argentina hubo aproximadamente 84500 visitas de pacientes ambulatorios (uno de cada ocho nacimientos) y 21000 hospitalizaciones de 4 días en promedio (uno de cada 31 nacimientos) asociadas con rotavirus, que en conjunto costaron unos US\$27,7 millones. Estos datos preliminares muestran que la carga de enfermedad por rotavirus en los niños argentinos es muy pesada y podría disminuirse con una vacuna segura y efectiva. Además se necesita ampliar la vigilancia para mejorar el conocimiento de la epidemiología y de la distribución de las cepas de rotavirus en el país, calcular más exactamente la eficacia en función del costo de un programa de vacunación antirrotavirus y determinar los mejores métodos de monitorear sus efectos. 